Snog-KJaer, A., Prange, I. \& Dam, H. (1956). J. gen. Microbiol. 14, 256-260

\title{
Conversion of Cholesterol into Coprosterol by Bacteria in vitro
}

\author{
By A. SNOG-KJAER, I. PRANGE AND H. DAM \\ Department of Biochemistry and Nutrition, Polytechnic Institute, Copenhagen, \\ Denmark
}

SUMMARY: Certain anaerobic bacteria from human faeces were found to be able to hydrogenate cholesteroli $n$ vitro; some also decreased to a marked degree the total amount of sterols in the incubation mixture. Other organisms did not hydrogenate or decrease the amount of sterols under the conditions chosen; among these were; Clostridium welchii, C. sporogenes, Bacterium bifidum, various streptococci and micrococci, Escherichia coli, Aerobacter aerogenes. A 'germ-free' filtrate from human faeces was inactive. In a series of incubated samples, where the Tschugaeff reaction was applied to the non-saponifiable matter, an orange colour developed, suggestive of the presence of lathosterol.

That hydrogenation of cholesterol can be carried out with human faeces or colon contents in vitro was demonstrated by Dam (1934b). At the same time it was shown that faeces heated at $100^{\circ}$ for $20 \mathrm{~min}$. failed to hydrogenate cholesterol. Certain bacteria in pure culture, such as Escherichia coli and a type B enterococcus were inactive. Later, Rosenfeld, Fukushima, Hellman \& Gallagher $(1954 a, b)$ succeeded in converting cholesterol into coprosterol with human faeces in vitro. Rosenheim \& Webster (1943) found that the bacteriostatic agent succinylsulphathiazole inhibited coprosterol formation in vivo in rats, but they also observed inhibition by the amoebicidal agent $p$-carbaminophenylarsonic acid which did not suppress the coliform flora. They therefore questioned the participation of bacteria in the process. The present work shows that cholesterol can be converted into coprosterol by some anaerobic bacteria from human faeces, whereas other such bacteria are inactive in this respect.

\section{METHODS}

Composition of media. Suspensions of brain were used as cholesterolcontaining substrate. Rosenheim \& Webster (1941) were of the opinion that cerebrosides such as those in brain are necessary for the hydrogenation of cholesterol in the intestine. However one of us (Dam, 1934a) found that, in man, faecal cholesterol was hydrogenated to more than $80 \%$ without ingestion of cerebrosides. Further, Rosenfeld et al. (1954a,b) used substrates without added cerebrosides in their in vitro experiments. The reason why we used brain suspensions as substrate is that such substrates are an easy means of providing a colloidal suspension of cholesterol which at the same time contains nutrients for bacteria. Desiccated hog or ox brain (2.5 or $5 \mathrm{~g}$. portions) were stirred with tap water to make $5 \%(\mathrm{w} / \mathrm{v})$ suspensions. In some cases, $1 \%(w / v)$ peptone and $0 \cdot 1 \%(w / v)$ glucose were also added. Undissolved 
matter was not filtered off. Sterilization was carried out for $30 \mathrm{~min}$. at $100^{\circ}$ (in live steam) on two consecutive days and for $30 \mathrm{~min}$. at $120^{\circ}$ on the third day. After the second heating $0 \cdot 1 \%(\mathrm{w} / \mathrm{v})$ of cysteine hydrochloride was added. In every experiment the contents of all flasks were adjusted to contain the same amount of the substrate.

Flasks inoculated with clostridia were pasteurized at $80^{\circ}$ for $7 \mathrm{~min}$. after addition of the clostridia, but before the addition of non-sporing bacteria.

After inoculation as described in Table 1 the mixtures were incubated in vacuo in the dark at $37^{\circ}$ for $7-8$ days. After incubation the contents of each flask were saponified with an equal volume of $60 \%(\mathrm{w} / \mathrm{w}) \mathrm{KOH}$ on a steam bath for 2-3 hr. on 2 or more days until all bulky material had been dissolved. The nonsaponifiable matter was shaken out with ether three times, the extract dried with anhydrous sodium sulphate, filtered, evaporated to dryness and the residue taken up in $25 \mathrm{ml}$. chloroform. The amount of dry matter in the chloroform solution was determined.

As a preliminary the Liebermann-Burchard reaction was carried out on all samples of the chloroform-soluble material. On some samples (Table 1, Exp. 4) Tschugaeff's reaction (see Hanel \& Dam, 1955), was also used. Thereafter samples were taken up in $96 \%(\mathrm{v} / \mathrm{v})$ ethanol in water and the total amount of sterols determined by precipitation with digitonin $(1 \%$, w/v, in $96 \%$ ethanol). The determination with digitonin was repeated after adjustment of the concentration of the sterol as found by the preliminary determination, to $0.5 \%(w / v)$, with a $50 \%$ excess of digitonin.

The amount of saturated sterol was determined in another sample by the bromine-digitonin procedure of Schönheimer (1930) with the slight modification that, when possible, the final determination was made with an ethanolic $(96 \%)$ solution containing $0.5 \%(\mathrm{w} / \mathrm{v})$ of saturated sterol.

In cases where a degree of hydrogenation above $90 \%$ was found, the saturated sterol was liberated from the digitonides by the pyridine-ether method (Schönheimer \& Dam, 1933), recrystallized from $96 \%$ ethanol and identified by crystal form, melting-point and melting-point of its mixture with a sample of coprosterol previously prepared from dog faeces.

\section{RESULTS}

The results are presented in Table 1. Expt. 1 shows (as found earlier: Dam, $1934 b$ ), that it is possible to hydrogenate cholesterol by incubation with human faeces in vitro. The same appears from Expt. $2 b$ and $c$. In cases where the incubation had resulted in hydrogenation of the sterols, the non-saponifiable matter was oily or largely oily, whereas it was crystalline in cases where hydrogenation of sterols had not occurred. Expt. $2 f$ shows that incubation with a 'germ-free' filtrate (i.e. free from dead organisms also) from the same faeces did not result in hydrogenation of cholesterol. Neither was hydrogenation obtained with a mixture of certain bacteria from the same faeces with or without addition of 'germ free' filtrate (Expt. $2 d, e)$. The inactive bacteria were various streptococci, micrococci, Escherichia coli, Aerobacter aerogenes and Bacterium bifidum. 


\section{Table 1}

\begin{tabular}{|c|c|c|c|c|c|}
\hline \multirow[b]{2}{*}{ Inoculum } & \multirow{2}{*}{$\begin{array}{l}\text { No. of days } \\
\text { incubated } \\
\text { at } 37^{\circ}\end{array}$} & \multirow{2}{*}{$\begin{array}{l}\text { Total } \\
\text { sterol } \\
\text { (mg.) }\end{array}$} & \multirow{2}{*}{$\begin{array}{l}\text { Saturation of } \\
\text { sterols } \\
(\%)\end{array}$} & \multicolumn{2}{|c|}{$\begin{array}{c}\text { Non-saponifiable } \\
\text { material }\end{array}$} \\
\hline & & & & mg. & Appearance \\
\hline Expt. 1. $10 \%$ & brain in & total v & $0 \mathrm{ml}$. & & \\
\hline g. sterilized $120^{\circ}, 15 \mathrm{~min}$. & 7 & 405 & $13 \cdot 5$ & 575 & Crystalline \\
\hline $\mathrm{g}$. & 7 & 350 & 80 & 690 & Oily \\
\hline
\end{tabular}

Expt. 2. $5 \%$ dried hog brain $+0 \cdot 1 \%$ cysteine hydrochloride in water, total vol. $50 \mathrm{ml}$.

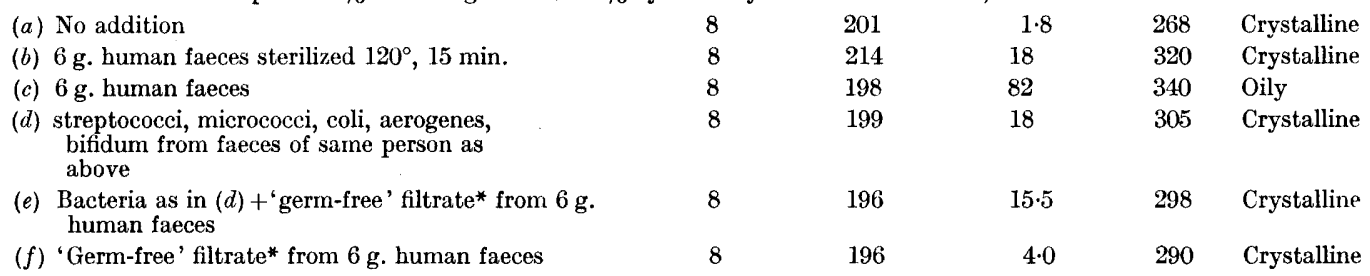

Expt. $3.5 \%$ dried ox brain $+0 \cdot 1 \%$ cysteine hydrochloride in water, total vol. $50 \mathrm{ml} .(\mathrm{pH} 7 \cdot 2$ )

(a) No addition

(b) Clostridium welchii

$8 \quad 220$

(c) C. sporogenes

(d) Anaerobic bacteria from human faecest

$220 \quad 2 \cdot 0 \quad 270$

Crystalline

$8 \quad 249$

$249 \quad 1 \cdot 5 \quad 310$

Crystalline

$8 \quad 258$

$258 \quad 2 \cdot 0 \quad 306$

(e) Anaerobic bacterium no. 103 from human faeces

136

$\begin{array}{cc}2 \cdot 0 & 306 \\ 89 & 385\end{array}$

(f) B. bifidum A9, $\$$ B. bifidum $\mathrm{K} 1 \S$

(g) Anaerobic bacteria nos. 101, 102, 106, 107 from

$229 \quad 2 \cdot 2$

8

8

$2 \cdot 2$

Crystalline

Oily human faeces

(h) Anaerobic bacterium no. 108 from human faeces

225

187

$2 \cdot 7$

$1 \cdot 8$

252

270

Crystalline

Crystalline

Crystalline

$8 \quad 226$

$3 \cdot 0$

250

Crystalline

$5 \%$ dried ox brain $+0.1 \%$ cysteine hydrochloride in water, total vol. $50 \mathrm{ml} .(\mathrm{pH} 7 \cdot 2)+1 \%$ peptone + $0.1 \%$ glucose

(i) Anaerobic bacteria from human faeces ||

8

26

80

315 Oily

Expt. $4.5 \%$ dried ox brain $+0 \cdot 1 \%$ cysteine hydrochloride in water, total vol. $100 \mathrm{ml}$. (pH 7.2)
(a) No addition
(b) Clostridia nos. 3 and 7 from hamster faeces
(c) Clostridia $\mathrm{M} 2+\mathrm{H} 2$ from human faeces
$\begin{array}{ll}8 & 465 \\ 8 & 465 \\ 8 & 478 \\ 8 & 105\end{array}$
$465 \quad 2 \cdot 1$
$65 \quad 5 \cdot 0 \quad 620$
$570 \quad$ Crystalline
$\begin{array}{lll}478 & 2 \cdot 4 & 680\end{array}$
(d) Anaerobic bacteria from human faeces as in
$105 \quad 77 \cdot 0$
738
Crystalline Expt. 3d
(e) Anaerobic bacteria from human faeces as in Expt. $3 i$
( $f$ ) Clostridia as in $b$ and $c+16$ different bacteria from
$8 \quad 114$
$79 \cdot 5$
730
Oily
8
493
$4 \cdot 8$
688
Oily
(g) Clostridia as in $c+$ bacteria nos. 120, 121, 122 and 123 from human faeces

$8 \quad 488$
$2 \cdot 3$
660
$8 \quad 267$
267
$\begin{array}{ll}8 & 260 \\ 8 & 442\end{array}$
93
773 Oily substrate $\mathscr{1}$
(i) Bacteria as in $c+h$
(j) Culture as in $d$ stored at $15^{\circ}, 6$ months

$93 \quad 800 \quad$ Oily
$92 \quad 760 \quad$ Oily

$5 \%$ dried ox brain $+0 \cdot 1 \%$ cysteine hydrochloride in water, total vol. $100 \mathrm{ml}$. $(\mathrm{pH} 7 \cdot 2)+$ $1 \%$ peptone $+0.1 \%$ glucose

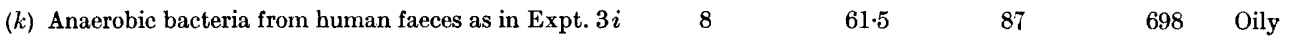

* The 'germ-free' filtrate from faeces was prepared by grinding $45 \mathrm{~g}$. faeces with $90 \mathrm{~g}$. water, centrifuging the mixture and passing the supernatant fluid through a sterile Seitz filter by suction.

$+5 \mathrm{~g}$. faeces were inoculated into $25 \mathrm{~g} .10 \%$ ox-brain extract $+0.1 \%$ cysteine $\mathrm{HCl}$, and incubated in vacuo at $37^{\circ}$ for 2 days; thereafter $0.5 \mathrm{ml}$. of the mixture was inoculated into another $25 \mathrm{~g}$. portion of the same substrate, incubated in vacuo as above; thereafter the same procedure was repeated 3 times.

$\ddagger$ Isolated from faeces of an old and presumably normal person.

$\$$ Isolated from infant less than six months of age.

If note + but $+1 \%$ peptone $+0.1 \%$ glucose in substrate

I This mixture of anaerobic bacteria was obtained by inoculating the bacteria used in Expt. $3 d$ into a $10 \%$ ox-brain extract to which had been added $\mathrm{CuSO}_{4}$ in an amount corresponding to $1 \mathrm{mg}$. $\mathrm{Cu} / 10 \mathrm{ml}$. medium. They were re-inoculated once into a similar substrate before use. 
Expt. 3 shows that Clostridium welchii and C. sporogenes, two strains of Bacterium bifidum, and some anaerobic bacteria from human faeces did not hydrogenate cholesterol under the conditions of the experiment, whereas certain anaerobic bacteria from human faeces gave a high degree of hydrogenation (Expt. $3 d, i$ ). These latter bacteria also decreased the total amount of sterol in the incubation mixture, especially when peptone and glucose had been added (Expt. $3 i$ ). In Expt. $4 d$, considerable hydrogenation of cholesterol was obtained by the same anaerobic bacteria as in Expt. $3 d$. Expt. $4 e, k$ show that these same bacteria also hydrogenated cholesterol, whether or not peptone and glucose had been added. When these anaerobic bacteria were grown in a medium containing $1 \mathrm{mg}$. $\mathrm{Cu} / 10 \mathrm{ml}$. their ability to hydrogenate cholesterol remained intact.

Expt. $4 d$ was repeated after the culture had been stored at $15^{\circ}$ for 6 months. The results (Expt. $4 j$ ) show that the ability to hydrogenate cholesterol had been retained, whereas the ability to convert cholesterol to non-digitonin precipitable substances was largely lost.

Several clostridia and bacteroides from human faeces did not hydrogenate (Expt. $4 b, c, f, g$ ).

The digitonides from the Expt. $4 h, i$ and $j$ were dissolved in pyridine and decomposed with ethyl ether according to Schönheimer \& Dam (1933), digitonides from $h$ and $i$ being pooled. After recrystallization from $96 \%$ ethanol the sterol obtained from $(h+i)$ melted at $98-100^{\circ}$, that from $j$ at 99 $101^{\circ}$. In both cases the crystals showed the needle form characteristic of coprosterol and showed no depression of melting-point after being mixed with a sample of coprosterol obtained from dog faeces. Attempts are being made to isolate, from the mixtures which were found active, purified cultures of organisms capable of hydrogenating cholesterol. In these mixtures Bacteroides spp. and pleuropneumonia-like organisms were especially evident.

In Expt. 4, where the Tschugaeff reaction was used, it was found that samples $c, d, e, h$, and $k$ gave an orange colour, suggesting the presence of lathosterol ( $\Delta^{7}$-cholestenol; cf. Hanel \& Dam, 1955). This recalls the finding of lathosterol in rat faeces reported by Wells, Coleman \& Bauman (1955).

\section{REFERENCES}

DAм, H. (1934a). The formation of coprosterol in the intestine. I. Biochem. J. 28, 815.

DAm, H. (1934b). The formation of coprosterol in the intestine. II. Biochem. J. 28, 820.

HANEL, H. \& Dam, H. (1955). Determination of small amounts of total cholesterol by the Tschugaeff reaction with a note on the determination of lathosterol. Acta chem. scand. 9, 677 .

Rosenfeld, R. S., Fukushima, D. K., Hellman, L. \& Gallagher, T. F. (1954a). Transformation of cholesterol to coprosterol. Fed. Proc. 13, 284.

Rosenfeld, R. S., Fukushima, D. K., Hellman, L. \& Gallagher, T. F. (1954b). The transformation of cholesterol to coprosterol. J. biol. Chem. 211, 301.

Rosenheim, O. \& Webster, T. A. (1941). A dietary factor concerned in coprosterol formation. Biochem. J. 35, 920. 
Rosenheim, O. \& Webster, 'T. A. (1943). The mechanism of coprosterol formation in vivo. Biochem. J. 37, 580 .

SchöNhermer, R. (1930). Methodik zur quantitativen Trennung von ungesättigten und gesättigten Sterinen. Hoppe-Seyl. Z. 192, 77.

Schönhemer, R. \& DAM, H. (1933). Ưber die Spaltbarkeit und Löslichkeit von Sterindigitoniden. Hoppe-Seyl. Z. 215, 59.

Wells, W. W., Coleman, D. L. \& Bauman, C. A. (1955). $\Delta^{7}$-Cholestenol in feces. Fed. Proc. 14, 303.

(Received 19 July 1955) 